\title{
Against the "Academic Intifada"
}

\section{David Hirsh}

$\Lambda$ $\mathrm{n}$ international campaign, based in Britain, for a boycott of Israeli artists, musicians, teachers, thinkers, writers, and researchers calls itself the "Academic Intifada." Two years ago, it proposed that the British Association of University Teachers (AUT) should require its members to blacklist colleagues who worked for Israeli universities. This boycott was rejected by the AUT.

This past year, the campaigners came back with what they thought was a more sophisticated approach. They argued for boycotts against particular Israeli institutions, in the hope that they would gather momentum for a total boycott in due course. They also responded to the objection that such boycotts would silence even Israeli academics who oppose the Occupation. They offered an exemption for professors who would denounce the "colonialist and racist" policies of Israel.

This political test would require that Israeli academics apply for exemption on the basis of their political cleanliness. The AUT would have endorsed the idea that "Zionists" had no place in academia, and some of its militants would have been tempted to extend the "Zionist" test to Jewish academics outside Israel.

Many in the Palestine Solidarity Movement have long claimed that "Zionism Equals Racism," that Israel is the only "illegitimate" state in the world, and that Jewish nationalism is irremediably worse than any other. This singling out of Jewish nationalism is anti-Semitic in effect, if not intention, because it licenses people to relate to Jews as though they were racists until they define themselves as "antiZionist." The Union of Jewish Students reports that campaigns to boycott Israel on campuses bring with them an increase in racist incidents against Jewish students.

An academic who comes originally from Poland wrote to me saying that the rhetoric of the boycotters reminded him of events there in 1968. Under the cover of solidarity with Palestinians, the Polish state had purged the Jewish intelligentsia. Jewish intellectuals were challenged to declare themselves anti-Zionist. Most of them refused, and many left the country; Poland lost a large number of its thinkers, teachers, writers, and researchers.

Something about the boycott effort brought a new group of people into open opposition. Personally, I had encountered some difficult moments while teaching. Some of my Masters students, for example, in a course on human rights, had created a swirl of half-baked antiSemitic narratives in response to a lecture on the complexities of Holocaust representation. "What about the Holocaust Industry?" "There is so much discussion of the Holocaust because of who controls the market." "Why does one group feel they own the Holocaust?" "The Holocaust myth." "It's the Zionists that insist on the ineffability of the Holocaust." In another class a student had repeated the claim that there were no Jews in the Twin Towers on September 11, 2001. I was already worrying about the connections between anti-imperialism, anti-Semitism, and hostility to Israel. Many colleagues had encountered similar attitudes in the classroom, in the union, and in public life more generally.

The mayor of London had hosted an Islamist cleric who had spoken in favor of suicide bombing against Israelis and had used unambiguous anti-Semitic language; the big anti-war demonstrations had linked opposition to the invasion of Iraq with demonization of Israel. Member of Parliament George Galloway claims that Jerusalem is in the hands of "foreigners," meaning Israeli Jews, who are perpetrating a rape of that city. 
Many of us had stopped worrying about Israel and Palestine during the peace process; we were jolted out of our complacency by the boycotters. I was in touch with a few old political colleagues, people with whom I had fought against the banning of Jewish societies in the student movement in the 1980s. A number of people were coming alive again politically.

We wrote a letter to the Guardian, articulating our case against the boycott and, at the same time, our opposition to the Occupation. This letter flew around academia and was published alongside a blander one opposing the boycott on the basis of academic freedom and another that opposed the boycott tactically but ambivalently. Each of these was signed by about a hundred academics.

We were surprised when the boycotters won the initial vote. The argument put to academic trade unionists this April was straightforward: Israel is an apartheid state, so boycott it. At first glance this is appealing to people disgusted by the realities of the Occupation. The vote was taken at the end of the meeting; there was no time for speeches against the boycott, and there had been little debate in the branches. Under these circumstances, some honest delegates voted for what was effectively an anti-Semitic policy.

The boycott was anti-Semitic because it singled out Israel and Israeli academics for special treatment with no morally or politically relevant reason for doing so. Israel is obviously not, as the boycott suggests, the worst human rights abuser, or the most racist state in the world; it is not responsible for the most serious campaign of ethnic cleansing.

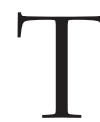

1 HOSE Who AGREE that Israel should be singled out fail to agree on why. Some say that the Jews should know better, that Israel claims to be a democracy and so should be held to a higher standard than states that do not; some say that Israel plays a particular role at the vanguard of global imperialism. One academic at an AUT branch meeting said that the role of Jews throughout history has been destructive to all around them. Some say that Israel is particularly culpable because it occupies Muslim land.
The most common reason is that Israel, as a Jewish state, is by definition racist. This is not a claim about what Israel does, but an existential claim about what Israel is. Racist policy is presented as the inevitable product of a racist essence (even by people who are otherwise opposed to essentialism). What drives them to such intellectual lengths?

The boycott campaign tolerated incidents of open anti-Semitism in its midst. Some activists referred to "rich and powerful Zionists" who would stand in the way of their campaign. The General Union of Palestinian Students allowed a leaflet to be circulated from its stall at a student conference that peddled the Protocols of the Elders of Zion.

These manifestations can't be unexpected. Campaigning against the boycott campaign, we argued for an analogy with institutional racism. Just as an institutionally racist police force does not necessarily contain racist officers, so parts of the left are politically hostile to Jews even if their activists do not feel anti-Semitic. But if you build a movement that is effectively if unconsciously anti-Semitic, then you cannot be surprised when it breeds and licenses hostility to Jews. Parts of the left in the United Kingdom are now allied with overt anti-Semitism, some of it Islamist, some of it native to its own ranks.

The boycott targeted the best of Israeli society. The universities are spaces where Jews and Arabs work, teach, learn, and think side by side; where debate rather than bloodshed is the norm. Haifa University and the Hebrew University have about 20 percent Palestinian students; there are Arab professors in all Israeli universities.

Ariel Sharon claims that all criticism of Israel is a manifestation of anti-Semitism. The boycotters say that criticism of Israel is not anti-Semitic. Both sides miss the point. Criticism of Israel is not necessarily anti-Semitic, but sometimes it is exactly that. Most critics of the boycott in the AUT are also critical of Israeli policy. But criticism that demonizes Israel and Jews lets Sharon off the hook; it moves the discussion onto ground where he can respond with righteous indignation. At the same time, it damages the most open and anti-racist institutions in Israel and pushes the already 
demoralized Israeli left toward the right.

The April decision plunged the AUT into crisis. A number of high-profile Jewish academics responded immediately with calls for resignation from the union. A group that had been doggedly fighting the boycott campaign for years declared that this was the final straw. But we wanted to be members of a union, and the AUT is the only one there is. We judged that it was better to take the fight into the union than to step outside, leaving it permanently in the hands of an unrepresentative minority. We decided to campaign against the boycott and set up the Web site Engage (www.liberoblog. com) to coordinate the campaign.

Jon Pike read the AUT rule book. "We can call a Special Council to discuss the issue," he told me on the phone, "if we get the signatures of twenty-five council members." Why not give it a go? So Jon worked within the union structures while I developed a Web site that would arm people with arguments for the coming debate. Jane Ashworth, with her huge experience of building campaigns, consolidated the network. A fresh wind of member participation blew through the cobwebbed cliques of the AUT. Open and democratic meetings were held in local branches, winning nearly all of them to anti-boycott positions.

The debate at the Special Council cannot be understood as a fight between the left and the right. Rather it was a fight between two souls of the left. There is a long tradition of anti-Semitism on the left and in the labor movement - the "socialism of fools" as August Bebel called it. The Stalinists in the 1930s organized anti-Semitic campaigns and ran the "doctors trials" in the 1950s. Before the Second World War, Oswald Moseley came out of the Labour Party to campaign on an antiSemitic platform in the East End of London. Since the 1967 Israeli-Arab war, left antiSemitism has disguised itself in the clothes of anti-Zionism. In the 1970s and 1980s the Soviet Union sent Jews who wanted to live in Israel to the Gulag. Anti-Zionists attacked the rights of Jewish students to organize Jewish societies in the UK in the 1980s. Since the collapse of the peace process, the attacks of September 11, and the War Against Terror, left and liberal currents that consider America to be the central force for evil in the world have gotten stronger; they have made both tacit and formal alliances with political Islamism and they have been responsible for a renewed focus on Israel and Jews as the vanguard of global imperialism.

Palestinians have come to symbolize the global struggle against imperialism while Jews have come to symbolize the veiled imperialist forces behind the fiction of "democratic values.” Jews are Nazi-Zionists, Jews are rich capitalists, Jews are scheming communists, Jews are the shady neocons pulling the strings of American imperialism in the interest of Israel. All this is the expression of a false and racist radicalism. The left has to reeducate itself so that it can recognize anti-Semitism when it sees it.

The AUT Special Council voted against the boycott and for the authentic values of the left. It voted for academic freedom and for democratic norms. At the same time, the council was almost unanimous in its conviction that Palestinians suffer unjustly under Israeli occupation. The boycotters argued that theirs was the only way to support Palestinians. British academics decided instead to make positive links with Israeli and Palestinian universities, engage in joint research, joint teaching, and exchanges of students and ideas.

The weekend before the Special Council, there was a very small demonstration in London for Palestinian freedom. Why is there no mass movement for this cause-in support, also, of the Israeli peace movement? The chief reason for this is that the existing Palestine Solidarity Campaign smells of anti-Semitism. Most people do not want to be involved with such a movement. In this way, the politics of Palestine solidarity does tremendous harm to Palestinians. Its unremitting hatred of Israel, its calls for divisive boycotts, its libeling of Jews as racists, and the crassness and one-sidedness of the stories it tells-none of this serves its ostensible cause.

The boycotters learned nothing from their defeat. They reacted with a new barrage of anti-Semitic rhetoric, insisting that they were defeated by a well-funded global Zionist lobby that pressured the AUT. They won the debate, they said, but were unable to counter the shad- 
owy power of Jews and Zionists.

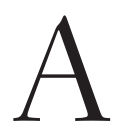
NTI-Semitism is on the rise in Europe and the UK. Some of the post-Holocaust taboos are withering; some are being bypassed with rhetoric referring to $\mathrm{Zi}$ onists rather than Jews. Implacable hostility to Israel functions as a centerpiece to some "antiimperialist" worldviews, not only on the left but also in right-wing isolationism. This problem is exacerbated by confused thinking about the distinction between Jihadi-Fascist movements, which incorporate hostility to Jews at the heart of their ideology, and Islam in general. Many people find it difficult to oppose the politics of those movements that claim to be the authentic voice of Islam. A wish to oppose anti-
Islamic racism sometimes slips into an implicit or overt alliance with Islam's self-appointed but in fact unrepresentative spokespeople.

Today, at last, there are people organizing to resist this fake leftism, educating themselves to recognize talk of Jewish lobbies and Zionist power as a sign of a cancer within our movement. Our Web site, Engage, is evolving into a network that challenges anti-Semitism on our campuses, in our labor movement, and in left and liberal discourse. Join us.

David Hirsh is a lecturer in sociology at Goldsmiths College, University of London, author of Law against Genocide: Cosmopolitan Trials (GlassHouse, 2004), and editor for Engage at www.liberoblog.com 